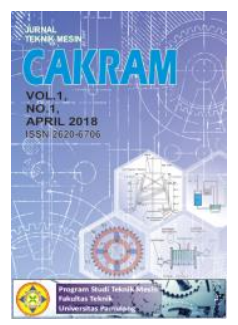

\title{
DETEKSI PROSES KOROSI PADA BAJA DENGAN MENGGUNAKAN LAPISAN AKRILIK TERMODIFIKASI PHENOLPHTHALEIN
}

\author{
Gadang Priyotomo

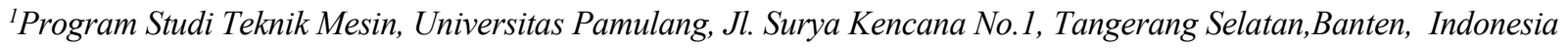 \\ E-mail : dosen01588@unpam.ac.id
}

Masuk : 2 Juni 2020

Direvisi : 24 Agustus 2020

Disetujui : 24 September 2020

\begin{abstract}
Abstrak: Masalah korosi merupakan salah satu pertimbangan biaya pemeliharaan dalam proses produksi industri minyak dan gas bumi, petrokimia dan geothermal. Salah satu metode mitigasi korosi adalah proses pelapisan polimer atau cat. Walaupun struktur di lapis oleh cat, proses korosi terjadi karena preparasi permukaan yang tidak benar. Proses deteksi dini korosi dibawah lapisan cat bisa salah satu kandidat untuk mengurangi kerusakan lebih lanjut. Material senyawa cerdik adalah phenolphthalein (PP) diperlukan sebagai indikator terjadinya korosi. Konsentrasi senyawa PP divariasikan dengan sebesar $0,01 \% ; 0,1 \%$ dan $1 \%$ yang diimbuhkan ke lapisan berbasis akrilik. Pengujian perfoma lapisan cat melalui pengujian kabut garam (ASTM B117-97) selama 240 jam. Metode visualisasi secara makro dilakukan untuk melihat kerusakan cat. Perfoma senyawa PP pada cat dengan konsentrasi $0,01 \%$ dan $1 \%$ memberikan indikasi bercak warna jingga di waktu ekspos 24 jam. Reaksi oksidasi dan reduksi (elektrokimia) berlangsung pada daerah antar muka lapisan cat dan substrak baja melalui visualisasi warna jingga.
\end{abstract}

Kata kunci: Korosi, Baja, Uji kabut garam, Ion hidroksil, Akrilik

\begin{abstract}
Corrosion problem is one of maintenance cost consideration in various production process of oil and gas, petrochemical and geothermal. One of corrosion mitigation method is polymer or coating. Even though the structure is coat by paint, corrosion process still carry on due improper surface preparation. The process of early detection of corrosion underneath paint layer could be as could as candidate of method for reducing the severity of corrosion. Phenolphthalein $(P P)$ as candidate of smart material is necessary to be proposed as an indicator material. PP compound in various concentration of $0.01 \%, 0.1 \%$ and $1 \%$ was added in acrylic base coat. The test of coating performance utilized salt fog test according to ASTM B117-97 with exposure time up to 240 hours. The observation of surface coating surface was used macro visual. On the basis of results, it shows that PP performance in the concentration of $0.01 \%$ and $1 \%$ turn to violet spot at 24 hours of exposure. Electrochemical reaction took place at interface between acrylic layer and metal base in which marked in violet color.
\end{abstract}

Keywords: Corrosion, Steel, Salt fog test, Hydroxyl ion, acrylic 


\section{PENDAHULUAN}

Korosi adalah reaksi penurunan kualitas material logam yang terjadi oleh reaksi sinergi antara logam dan lingkungan sekitarnya. Jenis kegagalan ini merupakan masalah yang umumnya sebagai pertimbangan biaya pemeliharaan proses produksi di industri antara lain minyak dan gas bumi, kimia, minuman dan makanan, manufaktur, geothermal dan lain-lain. Penurunan kuantitas dan kualitas produksi, biaya pemeliharaan yang tinggi dan tingkat keselamatan karyawan dapat terjadi jika kita tidak mempertimbangkan potensi korosi. Kerusakan akibat proses korosi juga menyebabkan dampak buruk aspek ekonomi secara makro antara lain kerusakan di pembangkit tenaga listrik uap, gas dan panas bumi. Pengendalian korosi diperlukan untuk meminimal kerusakan antara lain melalui seleksi material [1], proteksi katodik [2], pelapisan [3], dan inhibitor [4,5].

Lebih jauh lagi, peran material bersifat cerdik (smart material) di perlukan untuk mendeteksi kemampuan material untuk mendeteksi secara kimia, fisik dan mekanik secara visual dan terekam secara awal [6]. Tanda-tanda indentifikasi dapat terdeteksi melalui perubahan sifat dan struktur setelah terjadi proses terhadap lingkungan. Deteksi dini khususnya kegagalan akibat korosi sangat penting di dunia industri dan transportasi untuk mengurangi kerusakan lebih lanjut. Oleh karena itu, metode pengembangan pendeteksian awal akibat keberadaan proses elektrokimia atau korosi telah dilakukan secara intensif [7,8,9,10]. Namun penelitian teknologi indentifikasi awal korosi masih belum ada di Indonesia khususnya lapisan organik.

Reaksi korosi material merupakan reaksi elektrokimia dimana reaksi sinergis terjadi antara oksidasi (anoda) dan reduksi (katoda). Dua reaksi yang saling bersinergis ini dalam sel elektrokimia dapat diindentifikasi melalui fungsi dari senyawa material cerdik. Reaksi pada daerah katodik merupakan reaksi reduksi oksigen $\left(\mathrm{O}_{2}\right)$ dan air $\left(\mathrm{H}_{2} \mathrm{O}\right)$ dimana akan menghasilkan produk ion hidroksil $\left(\mathrm{OH}^{-}\right)$. Reaksi ini hanya bisa berlangsung jika lingkungan netral atau cenderung basa. Reaksi elektrokimia di daerah katodik terlihat pada reaksi dibawah ini :

$$
\mathrm{O}_{2}+2 \mathrm{H}_{2} \mathrm{O}+4 \mathrm{e}^{-} \rightarrow 4 \mathrm{OH}^{-}
$$

Korosi pada lapisan cat yang diaplikasikan pada material baja terjadi karena unsur persiapan permukaan substrak baja yang tidak bersih dan lembab saat proses pengecatan. Sehingga batas antara lapisan cat dan baja mengalami reaksi elektrokimia lokal sehingga terjadi korosi. Reaksi reduksi dapat menyebabkan peningkatan nilai $\mathrm{pH}$ secara lokal karena keberadaan ion hidroksil $\left(\mathrm{OH}^{-}\right)$berlimpah dibandingkan reaksi anodik [11], sehingga senyawa material cerdik dalam lapisan cat berkerja saat peningkatan nilai $\mathrm{pH}$ di daerah katodik. Penelitian ini menggunakan lapisan cat organic berbahan dasar akrilik sebagai binder. Cat berbasis akrilik merupakan cat kering cepat dimana pengikatnya merupakan senyawa polimer gugus akrilik [12]. Umumnya, cat berbasis akrilik ini dapat larut dalam media air (water borne acrylic) namun cat ini bersifat tahan air saat kering di udara terbuka.

Polimer akrilat adalah grup polimer dimana sifat fisiknya jernih, elastic dan daya lekat yang kuat. Polimer akrilat (poliakrilat) adalah kumpulan banyak monomer akrilat. Monomer-monomer ini adalah turunan dari asam akrilik metil-methakrilat bersama gugus satu vinil hidrogen dan hidrogen asam karbosilik yang keduanya ditukar oleh grup gugus metil. Gugus akrilonitril pada grup asam karbosilik ditukar oleh grup nitril terlihat pada Gambar 1 .

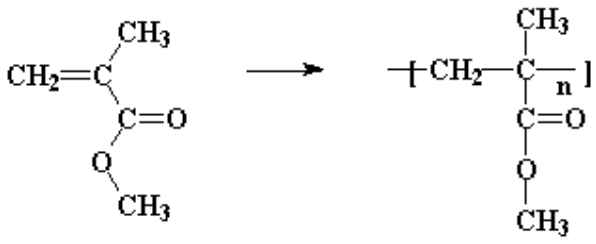

Gambar 1. Polimerasi metil metaakrilat menjadi poly(metil metaakrilat)

Pelapisan akrilik dengan tambahan zat aditif material cerdik berupa phenolphthalein (PP) sebagai indikator warna saat terjadi peningkatan $\mathrm{pH}$. Namun, penelitian ini belum ada investigasi lebih dalam khususnya senyawa PP pada cat berbasis akrilik. Oleh karena itu, tujuan penelitian ini adalah (1) untuk mengetahui kinerja material PP sebagai indikator yang diterapkan lapisan akrilik di lingkungan atmosfer garam dan menjelaskan mekanisme material cerdik imbuhan PP di lapisan akrilik. 


\section{METODOLOGI}

2.1 Persiapan logam substrak

Sampel substrak yang akan dilapis cat akrilik adalah baja karbon berbentuk pelat. Pelat baja karbon tersebut dipotong dengan ukuran $750 \mathrm{~mm}$ x $150 \mathrm{~mm}$ x $2 \mathrm{~mm}$. Permukaan substrak logam tersebut dibersihkan dari karat dan pengotor lainnya secara mekanik dengan menggunakan pasir material silika berukuran mesh $-60+80$ melalui alat sand blasting hingga permukaan benda uji bebas karat dan bersih yang terlihat pada Gambar 1. Setelah itu, sampel pelat dibersihkan dengan larutan aseton di dalam mesin ultrasonic cleaner untuk membersihkan lemak dan debu.

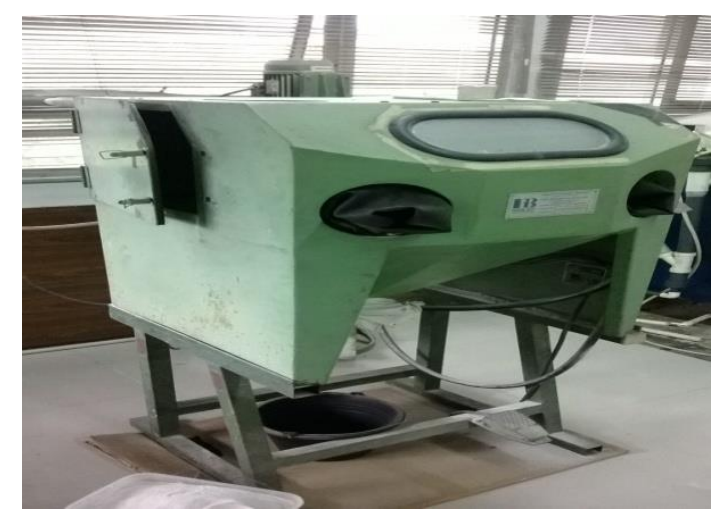

Gambar 1. Mesin sand blasting

\subsection{Proses pelapisan cat}

Proses pencampuran bahan aditif phenolphthalein (PP) dengan water-borne acrylic dilakukan dengan menvariasikan konsentrasi senyawa PP sekitar $0,01 \%, 0.1 \%$ dan $1 \%$. Proses pelapisan melalui campuran PP menggunakan metode brushing dengan kuas dimana harus dilapis secara merata dan perlahan, kemudian dibiarkan mengering di udara terbuka hingga 24 jam yang terlihat pada Gambar 2. Suhu ruangan saat pengeringan dipertahankan $30^{\circ} \mathrm{C}$. Semua sampel uji yang terlapis cat disimpan di desikator vakum. Setelah itu, Pada Gambar 3 sampel uji dimasukan ke dalam ruang kabut garam berstandar ASTM B117-97. Standar tersebut menjelaskan bahwa konsentrasi garam sodium klorida $(\mathrm{NaCl})$ berkisar 3,5\%; $\mathrm{pH}$ antara 6,5-7,2 $\mathrm{pH}$ dan temperatur $35^{\circ} \mathrm{C}$ [13]. Posisi penempatan pelat sampel adalah bersudut $45^{\circ} \mathrm{C}$. Interval waktu uji kabut garam adalah 2, 24, 48 dan 240 jam. Setelah uji, spesimen cat dikeluarkan, dibersihkan dengan air distilasi dari garam-garam yang melekat serta dikeringkan. Ketebalan lapisan cat akrilik diukur dengan menggunakan alat uji ketebalan ELCOMETER 456. Pengamatan dalam kegiatan riset ini dilakukan secara visual sebelum dan sesudah ekspos dengan menggunakan foto secara makro di laboratorium. 


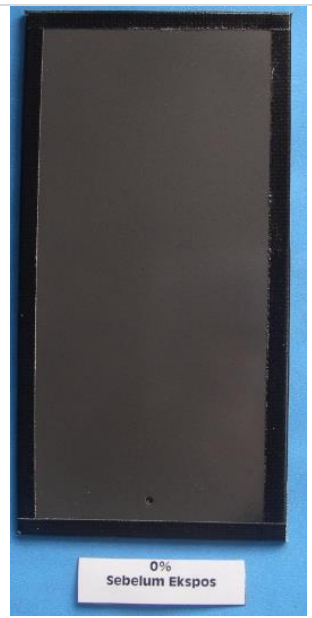

Gambar 2. Sampel uji cat akrilik bening sebelum uji kabut garam

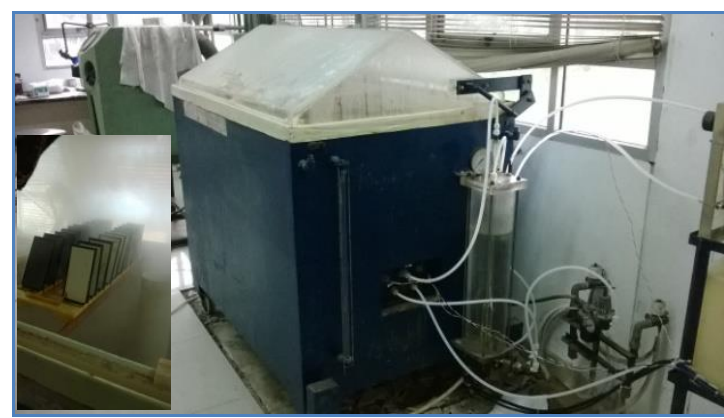

Gambar 3. Alat pengujian kabut garam dengan standar ASTM B117-97

\section{HASIL DAN PEMBAHASAN}

Tabel 1 memperlihatkan hasil uji kabut garam sampel cat dengan variasi indikator senyawa PP pada interval 2, 4, 24, 48 dan 240 jam dimana sampel cat tanpa senyawa indikator sebagai referensi. Unjuk kerja senyawa PP tidak terlihat pada ekspos 2 jam pada seluruh variasi konsentrasi indicator dimana warna jingga terlihat pada konsentrasi $0.1 \%$ dan 1\% PP pada ekspos 4,24,48 dan 240 jam. Penambahan $0.01 \%$ PP pada lapisan cat akrilik tidak memberikan indikasi warna jingga diseluruh interval ekspos. Lebih jauh lagi, perambatan tingkat korosi semakin besar seiring peningkatan waktu ekspos uji. Berdasarkan hasil, sensitivitas deteksi dapat terlihat pada cat akrilik dengan imbuhan konsentrasi senyawa cerdik PP berkisar $0.1 \%$ pada waktu ekspos 24 jam. Disisi lain, pada rentang ekspos seluruh rentang waktu uji, tidak ada proses pelepuhan (blistering) yang terjadi pada lapisan cat akrilik. Ini disebabkan proses pelapisan cat akrilik dijaga agar suhu ruang diatas $3^{\circ} \mathrm{C}$ suhu embun (dew temperature) sehingga tidak ada kondensasi (pengembunan) di permukaan substrak. 
Gadang Priyotomo, Deteksi Proses Korosi Pada Baja Dengan Menggunakan Lapisan Akrilik Termodifikasi Phenolphthalein

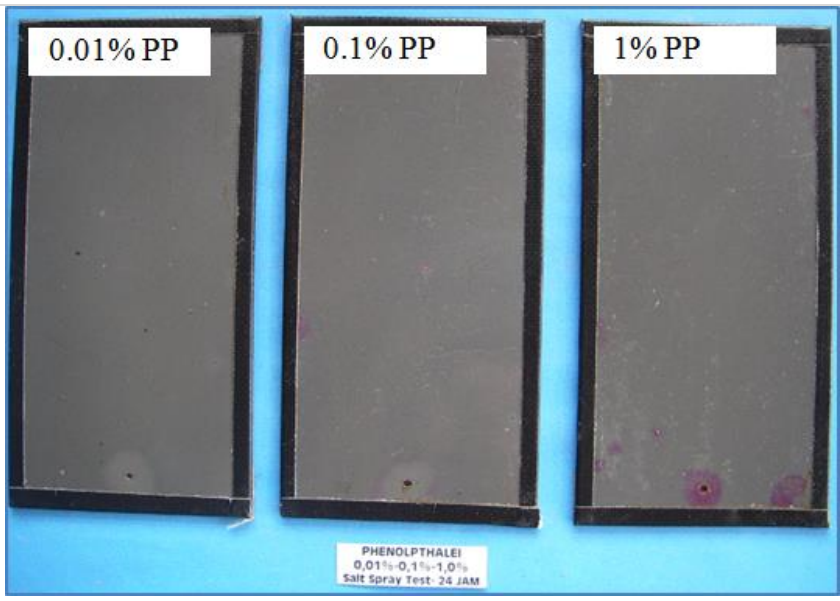

Gambar 4. Foto visual spesimen baja yang dilapis cat akrilik berbagai konsentrasi PP dengan waktu uji 24 jam

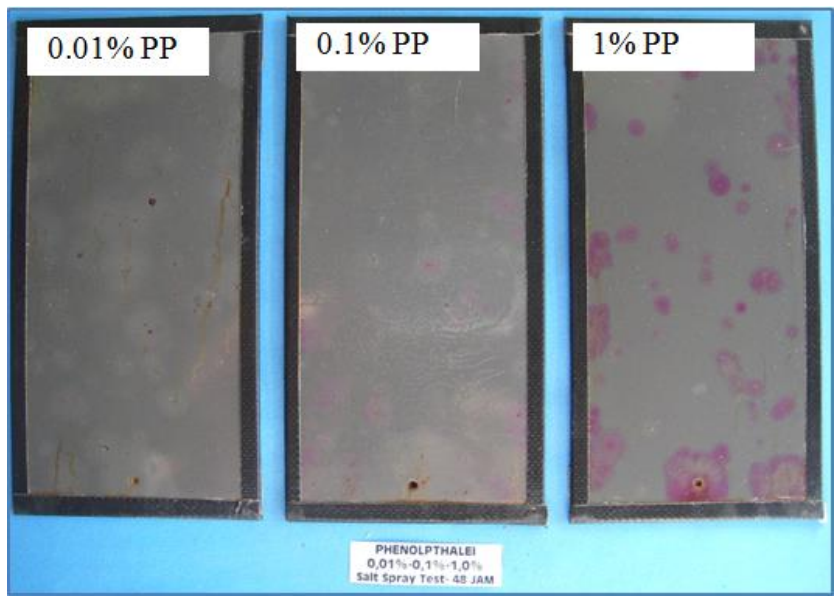

Gambar 5. Foto visual spesimen baja yang dilapis cat akrilik berbagai konsentrasi PP dengan waktu uji 48 jam

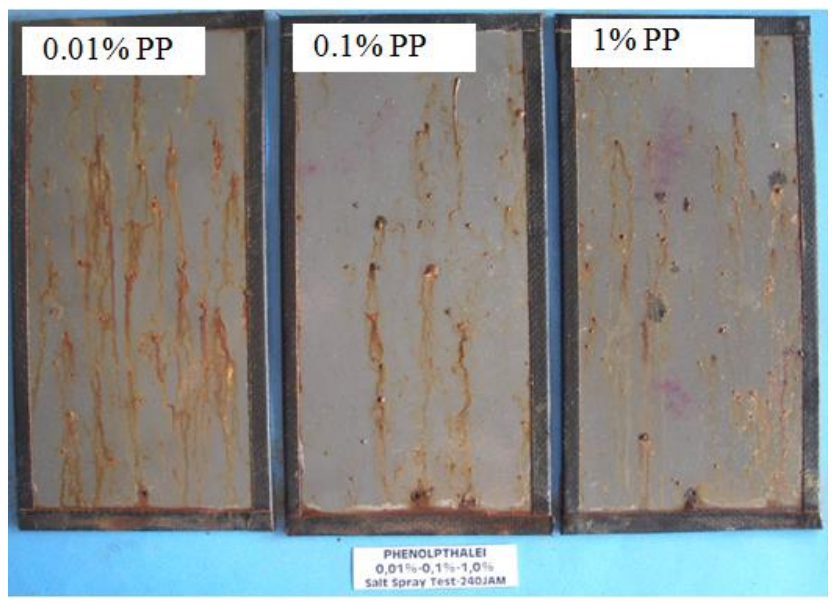

Gambar 6. Foto visual spesimen baja yang dilapis cat akrilik berbagai konsentrasi PP dengan waktu uji 240 jam 
Jurnal Teknik Mesin: CAKRAM 2020

Gadang Priyotomo, Deteksi Proses Korosi Pada Baja Dengan Menggunakan Lapisan Akrilik Termodifikasi

Phenolphthalein

Lebih jauh lagi, Pada Gambar 4, 5 dan 6 memperlihat urutan penambahan konsentrasi aditif senyawa PP ke dalam cat akrilik, dimana indikator warna bekerja efektif pada konsentrasi $0.1 \%$ PP. Setelah indikator warna muncul, karat akan nampak selanjutnya. Fenomena ini memberikan informasi bahwa senyawa PP cukup efektif sebagai penanda sebelum proses korosi lebih lanjut terlihat secara visual. Perambatan karat berwarna merah menandakan bahwa proses korosi telah masuk ke logam dasar baja. Keberadaan garam sodium klorida ( $\mathrm{NaCl})$ sebagai inisiator pemercepat terjadinya korosi telah meningkatkan laju korosi hingga 24 jam, dimana peran ion $\mathrm{klorida}\left(\mathrm{Cl}^{-}\right)$ memecah lapisan pasif baja [14,15]. Lapisan akrilik bening yang terlapis pada substrak baja umumnya mengalami kerusakan korosi filiform (filiform corrosion), dimana umumnya terjadi di daerah antara lapisan dan substrak logam[17]. Kerusakan jenis korosi ini terjadi pada ketebalan maksimum lapisan hingga $1000 \mu$ m. Pada penelitian ini, ketebalan maksimum lapisan akriklik bening di bawah $80 \mu \mathrm{m}$ [18].

Tabel 1. Uji kabut garam pada sampel uji cat, waktu ekspos hingga 240 jam dengan variasi konsentrasi indikator PP

\begin{tabular}{|c|c|c|c|c|c|c|c|}
\hline \multirow{3}{*}{$\begin{array}{c}\text { Konsentrasi } \\
\text { PP (\%) }\end{array}$} & \multirow{3}{*}{$\begin{array}{c}\text { Tebal } \\
\text { lapisan } \\
(\mu \mathrm{m})\end{array}$} & \multicolumn{6}{|c|}{ Waktu uji ( jam) } \\
\hline & & \multicolumn{2}{|r|}{2} & \multicolumn{2}{|c|}{4} & \multicolumn{2}{|c|}{24} \\
\hline & & Pelepuhan & Indikasi & Pelepuhan & Indikasi & Pelepuhan & Indikasi \\
\hline 0 & 60.6 & tidak ada & tidak ada & tidak ada & tidak ada & tidak ada & tidak ada \\
\hline 0.01 & 63.6 & tidak ada & tidak ada & tidak ada & tidak ada & tidak ada & tidak ada \\
\hline 0.1 & 71.6 & tidak ada & tidak ada & tidak ada & tidak ada & tidak ada & ada \\
\hline 1 & 51.8 & tidak ada & tidak ada & tidak ada & tidak ada & tidak ada & ada \\
\hline \multirow{3}{*}{$\begin{array}{c}\text { Konsentrasi } \\
\text { PP }(\%)\end{array}$} & Tebal & \multicolumn{6}{|c|}{ Waktu uji ( jam) } \\
\hline & lapisan & \multicolumn{2}{|c|}{48} & \multicolumn{2}{|c|}{72} & \multicolumn{2}{|c|}{240} \\
\hline & $(\mu \mathrm{min})$ & Pelepuhan & Indikasi & Pelepuhan & Indikasi & Pelepuhan & Indikasi \\
\hline 0 & 60.6 & tidak ada & tidak ada & tidak ada & Karat & tidak ada & Karat \\
\hline 0.01 & 63.6 & tidak ada & warna jingga & tidak ada & warna jingga & tidak ada & warna jingga \\
\hline 0.1 & 71.6 & tidak ada & warna jingga & tidak ada & warna jingga & tidak ada & warna jingga \\
\hline 1 & 51.8 & tidak ada & warna jingga & tidak ada & warna jingga & tidak ada & warna jingga \\
\hline
\end{tabular}

\subsection{Mekanisme kinerja senyawa phenolphthalein}

Penampakan visual warna jingga dengan indikator PP menandakan adanya reaksi elektrokimia sedang bekerja secara simultan di antara lapisan akrilik dan substrak baja [17]. Elektrokimia merupakan proses menghasilkan elektron dan arus listrik ,dimana merupakan reaksi sinergis antara anodik dan katodik [18]. Gambar 7 memperlihatkan skema sel elektrokimia di bawah lapisan akrilik. Lapisan akrilik merupakan lapisan dengan kelebihan daya kilap yang bagus, ketahanan warna yang baik (tidak mudah pudar), anti ultra violet dan cukup tahan terhadap asam dan alkali. Namun, fenomena retak lapisan juga terjadi saat pengaplikasian. Retak lapisan akrilik yang menembus hingga logam dasar dapat terjadi dan diperparah dengan kondisi lingkungan garam sodium klorida $(\mathrm{NaCl})$ dan berkelembaban diatas 80\%[16].

Keberadaan retakan pada lapisan memberikan kesempatan oksigen $\left(\mathrm{O}_{2}\right)$ masuk ke dalam logam dasar dan mulai mengalami reaksi katodik dengan mengubah $\mathrm{O}_{2}$ dan air $\left(\mathrm{H}_{2} \mathrm{O}\right)$ menjadi ion $\mathrm{OH}^{-}$dimana elektronnya disuplai dari reaksi anodik. Reaksi anodik terjadi dengan mengkonversi logam Fe menjadi ion Fe dengan melepas elektron. Kombinasi sinergis lingkungan yang lembab dan keberadaan oksigen meningkatkan kegagalan korosi seiring dengan peningkatan waktu ekspos uji. Kegagalan korosi ini diperparah dengan ion klorida melalui senyawa garam saat masuk ke dalam ruang kabut garam. 


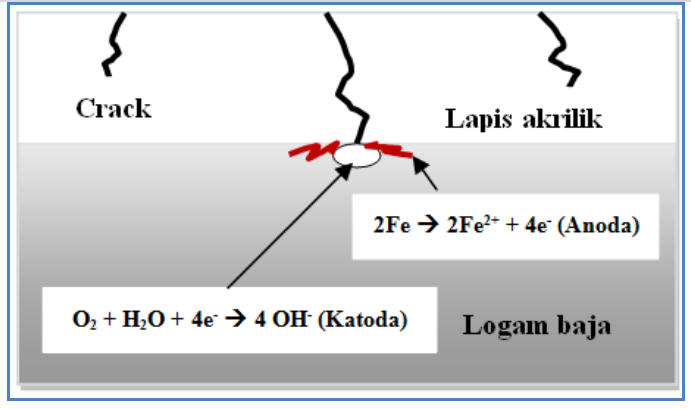

Gambar 7. Skema sel elektrokimia di bawah lapisan akrilik

Daerah katodik menghasilkan ion hidroksil $\left(\mathrm{OH}^{-}\right)$yang berlimpah dengan ditandai peningkatan nilai $\mathrm{pH}$ pada daerah secara lokal [19]. Senyawa phenolphthalein bekerja efektif pada nilai pH 10 ditandai warna jingga [20]. Penelitian ini memperlihatkan bahwa warna jingga muncul di lapisan akrilik pada waktu ekspos 24 jam kemudian menghilang seiring terbentunya deposit karat pada waktu ekspos 240 jam. Ini dimungkinkan bahwa pembentukan ion $\mathrm{OH}^{-}$terjadi pada waktu ekspos 24 jam kemudian ion tersebut berikatan dengan ion Fe menjadi senyawa besi hidroksida (warna merah). Besi hidroksida mempunyai nilai pH 7 dimana ini menyebabkan warna jingga menghilang seiring meningkatan waktu ekspos.

\section{KESIMPULAN}

Penambahan konsentrasi senyawa phenolphthalein (PP) $0.1 \%$ dan $1 \%$ di sistem cat berbasis akrilik sangat efektif mendeteksi kegagalan korosi di bawah lapisan pada waktu ekspos 24 jam, dimana konsentrasi PP $0.01 \%$ tidak terlihat. Reaksi reduksi pada daerah katodik menghasilkan ion hidroksil $\left(\mathrm{OH}^{-}\right)$ditandai nilai $\mathrm{pH}$ tinggi menciptakan sensitivitas senyawa indikator $\mathrm{PP}$ dengan menampakan visual warna jingga. Peningkatan waktu ekspos uji kabut garam meningkatkan kerentanan korosi terhadap lapisan akrilik.

\section{DAFTAR PUSTAKA}

[1]. Gadang Priyotomo, Siska Prifiharni, Lutviasari Nuraini, Sundjono, Ibrahim Purawiardi. "Korosi Baja di uara Baru Jakarta dan Indramayu dengan Simulasi Pasang Surut Uji Wet-Dry." Jurnal Kelautan 12 (1) (2019): 23-35.

[2]. Sundjono, Gadang Priyotomo and Lutviasari Nuraini. "The Selection of Magnesium alloys as Sacrificial Anode for the Cathodic Protection of Underground Steel Structure.” international journal of engineering trends and technology 51 (2017): 78-82.

[3]. F. O. Kolawole, S. K. Kolawole, J. O. Agunsoye, J. A. Adebisi, S. A. Bello, S. B. Hassan, "Mitigation of Corrosion Problems in API 5L Steel Pipeline - A Review", Journal of Materials and Environmental Sciences, Vol 9 (8),(2018): 2397-2410.

[4]. Yulinda Lestari, Gadang Priyotomo,2018, "Corrosion resistance of API 5L grade B steel with taro leaf (Colocasia esculenta) addition as corrosion inhibitor in $\mathrm{HCl} 0.1$ M", AIP Conference Proceedings 1964, 020031.

[5]. Gadang Priyotomo, Siska Prifiharni, Lutviasari Nuraini, Yanyan Dwiyanti, Rabin Ardiansyah, "A Study on Dimocarpus longan Peel as Corrosion Inhibitor on Steel in Artificial Brine Solutions", Research \& Development in Material Science, Vol 6(2) (2018): 555-558.

[6]. Nazeer, Ahmed Abdel, and Metwally Madkour. "Potential Use of Smart Coatings for Corrosion Protection of Metals and Alloys: A Review.” Journal of Molecular Liquids, Vol 253 (2018) : 11-22. 2018.

[7]. Calle, Luz M., Paul E. Hintze, Wenyan Li, and Jerry W. Buhrow. 2010. "Smart Coatings for Autonomous Corrosion Detection and Control.” In AIAA SPACE Conference and Exposition 2010. 
[8]. Augustyniak, Anita, John Tsavalas, and Weihua Ming. 2009. "Early Detection of Steel Corrosion Via 'turn-On' fluorescence in Smart Epoxy Coatings.” ACS Applied Materials and Interfaces 1 (11): 261823.

[9]. He, Zhen, Yuelong Huang, Aswin K. Manohar, and Florian Mansfeld. "Effect of Electrolyte pH on the Rate of the Anodic and Cathodic Reactions in an Air-Cathode Microbial Fuel Cell.” Bioelectrochemistry 74, no. 1 (2008): 7882.

[10]. Galvão, T. L.P., N. Scharnagl, I. Sousa, F. Maia, M. Wilhelm, J. R.B. Gomes, J. Opršal, et al. 2018. "Nanostructured Corrosion Sensing Coatings for Aeronautical Applications." In NACE - International Corrosion Conference Series. Vol. 2018-April.

[11]. ASTM Handbook, (2007), Standard Practice for Operating Salt Spray (Fog) Apparatus; ASTM B117-07, ASTM Metal Test Methods and Analytical Procedures Section 3, p 1-10.

[12]. Priyotomo, Gadang, Lutviasari Nuraini, Siska Prifiharni, and S Sundjono. "Corrosion Behavior of Mild Steel in Seawater from Karangsong \& Eretan of West Java Region, Indonesia." Jurnal Kelautan: Indonesian Journal of Marine Science and Technology 11, no. 2 (2018): 184. https://doi.org/10.21107/jk.v11i2.4335.

[13]. Priyotomo, Gadang, Siska Prifiharni, Lutviasari Nuraini, S Sundjono, and Ibrahim Purawiardi. "KOROSI BAJA DI MUARA BARU JAKARTA DAN INDRAMAYU DENGAN SIMULASI PASANG SURUT UJI WET-DRY." Jurnal Kelautan: Indonesian Journal of Marine Science and Technology 12, no. 1 (2019): 23. https://doi.org/10.21107/jk.v12i1.4800.

[14]. Popov, Branko N. "Chapter 01: Evaluation of Corrosion." Corrosion Engineering, 2015, 1-28. https://doi.org/10.1016/b978-0-444-62722-3.00001-X.

[15]. Buchheit, Rudolph G. "Corrosion Resistant Coatings and Paints." In Handbook of Environmental Degradation Of Materials: Third Edition, 449-68, 2018. https://doi.org/10.1016/B978-0-323-52472-8.00022-8.

[16]. Priyotomo, Gadang, Lutviasari Nuraini, Siska Prifiharni, and S Sundjono. "Corrosion Behavior of Mild Steel in Seawater from Karangsong \& Eretan of West Java Region, Indonesia.” Jurnal Kelautan: Indonesian Journal of Marine Science and Technology 11, no. 2 (2018): 184. https://doi.org/10.21107/jk.v11i2.4335.

[17]. "External Corrosion of Oil and Natural Gas Pipelines.” In Corrosion: Environments and Industries, 1015-25, 2018. https://doi.org/10.31399/asm.hb.v13c.a0004213.

[18]. Petruševski, Vladimir M., and Keti Risteska. "Behaviour of Phenolphthalein in Strongly Basic Media." Chemistry 16, no. 4 (2007): 259-65. 